(ICSSE 2020)

\title{
Leadership of Tourism and Culture Department in Development of Cultural Reserves at District Kuantan Singingi
}

\author{
Andri Satria ${ }^{1}$ Moris Adidi Yogia ${ }^{1 *}$ Zainal $^{1}$ Made Devi Wedayanti ${ }^{1}$ Khairul Rahman ${ }^{1}$ \\ Astri Ayu Purwati ${ }^{2}$ \\ ${ }^{1}$ Universitas Islam Riau, Indonesia \\ ${ }^{2}$ Institut Bisnis dan Teknologi Pelita, Indonesia \\ ${ }^{*}$ Corresponding author. Email: moris.adidiy@soc.uir.ac.id
}

\begin{abstract}
The Tourism and Culture Office of Kuantan Singingi Regency has a very important role in developing and caring for these historical objects and cultural heritage, there is a program of the Tourism and Culture Office to achieve the stated goals and objectives, namely, human resource development in the tourism sector, development of cultural values traditional Kuantan Singingi, fostering and developing regional arts, tourism development of Kuantan Singingi Regency, promotion and documentation of tourism and culture. The research method used in this research is to use qualitative methods. From the information obtained by researchers, it shows that the development of tourism in Kuantan Singingi Regency is indeed the leader who becomes the sole actor because the function of a leader is to organize and organize properly so that tourism can develop into good tourism and provide input to income for the local government of Kuantan Singingi Regency. The conclusion of this study shows that the leadership of the Kuantan Singingi Regency Tourism and Culture Office has not been maximal in carrying out its duties according to the role and function of the Government.
\end{abstract}

Keywords: Leadership, Governance, Tourism and Development

\section{INTRODUCTION}

The cultural heritage buildings are built structures made of natural objects or man-made objects to meet the needs for space with walls and or without walls, and with roofs. The structure of cultural heritage is a built-in structure, which is made of natural objects and/or man-made objects to meet the needs of activity space that is integrated with nature, facilities and infrastructure to accommodate human needs. A cultural heritage site is a location on land and in water containing cultural heritage objects and cultural heritage structures as a result of human activities or evidence of past events. Meanwhile, a cultural heritage area is a geographic space unit that has two or more cultural heritage sites that are adjacent to each other and show distinctive spatial characteristics.

Viewed from the political aspect of cultural heritage, it can be used to designate one aspect of human life together in society, namely the aspect of human political life, the aspect of social life which concerns power relations. In this sense, it contains political content as an effort to gain power, enlarge or expand and maintain power. Two, politics in the sense used to refer to a series of goals to be achieved, or certain ways or directions of activities to achieve goals, or in a shorter word is wisdom.

This new trend has contributed more to the description of archaeological remains in a more complete and more systematic way than has ever been done before. More significantly, especially in colonial countries, the emergence of a nationalistic aceology "when mixed with a sense of concern for the dignity of human existence", has helped fight against colonialism and racism, both of which often take on the guise [1].

The quotation of the governmental decentralization paradigm shows that in the current management of cultural heritage it will not be separated from the regional autonomy government system. The local government management system is run based on decentralization, deconcentration and assistance. This government system in its implementation has not provided clarity on how it should be institutionalized in the government system. The three principles of government actually want to clarify the relationship of authority between the central government and regional governments [2]. Therefore, when we just follow this system in the management of cultural heritage, of course there will be an essence of work bias towards it, given that cultural heritage preservation work is a special job and is full of academic content.

The most important thing when cultural heritage is viewed from a cultural aspect is that cultural heritage as a cultural resource is fragile, unique, rare, limited, and nonrenewable. This characteristic causes the number to tend to decrease as a result of exploitation that does not pay attention to its protection efforts, although the age limit of 50 years as the starting point for determining the status of 
"exaltedness" of objects gradually places old objects, buildings or structures into new cultural heritage. Older inheritance, because it cannot be replaced by new ones, will continue to decrease irreversibly.

At the Tourism and Culture Office, it has been recorded as a cultural heritage site, the government's lack of attention to history and heritage sites in the Kuantan Singingi area. And his indifference, the community and the youth towards the cultural heritage, causing the ignorance of the history of knowledge of the Kuantan Singi region itself.

From the data, it can be seen that the budget for the Tourism and Culture Office of Kuantan Singingi Regency is the largest in 2016, while the smallest budget is in 2014 . However, this budget does not include the maintenance and development of cultural heritage in each District in the Regency. Kuantan Singingi, while in Kuantan Singingi District, there are 15 sub-districts with cultural heritage and the name of cultural heritage for each district in Kuantan Singingi Regency.

The Tourism and Culture Office of Kuantan Singingi Regency plays an important role in developing and caring for these historical objects and cultural heritage, there is a program of the Tourism and Culture Office in order to achieve the stated goals and objectives, namely, human resource development in the tourism sector, development of cultural values Traditional Kuantan Singingi, Fostering and developing regional arts, tourism development of Kuantan Singingi Regency, promotion and documentation of tourism and Kuantan Singing culture, preparation of regional law products regarding tourism taxes and levies. Several efforts for the development and maintenance of cultural heritage were carried out by the cultural, tourism, youth and sports services.

\section{LITERATURE REVIEW \\ 2.1 Administration Concept}

[3] In terminology, what is called administration is managing, managing, managing. If it is affixed with the prefix and meaning in each meaning, then everything implies that there is order and arrangement of causes which are the targets of control, management and what's more, regulation is the creation of order in the arrangement and arrangement of its dynamics.

According to [4] that the definition of administration is of two kinds, namely administration in a narrow sense and administration in a broad sense. Administration in a narrow sense is the activity of systematically compiling and recording data and information with the aim of providing information and making it easier to retrieve it as a whole and in one relationship to one another. Administration in this narrow sense is actually more accurately called administration. While administration in a broad sense is a collaborative activity carried out by a group of people based on the division of labor as determined in the structure by utilizing resources to achieve goals effectively and efficiently. The definition of administration in a broad sense has elements of a group of people, cooperation, a structured division of tasks, activities that are coherent in the process, goals to be achieved, and the use of various sources.

Many opinions say that management is part of the administration as above and vice versa. Actually both of them depend on the place or country where the opinion comes from [5]. On other occasions, administrative experts generally agree that management is the core of administration and leadership is the core of management [4].

[6] that the notion of administration can be viewed from an institutional point of view, namely the administration of the whole person or group of people as a unit carrying out the process of activities to achieve common goals; whereas from a functional point of view, that is all activities and actions taken to achieve goals, including actions to determine the goals themselves, these actions are forward looking".

The same opinion was expressed by John M Pfiffner in [7] saying that administration is a process activity, especially regarding the means (means) of means to achieve predetermined goals. Administration can also be defined as organizing and directing human, labor, and material resources to achieve the desired goals.

\subsection{Government Leadership Concept}

The concept of leadership is essentially comprehensive, touching various aspects of life. The concept of leadership is also a logical consequence of the life of human civilization, both pre-modern and modern. Starting from the religious context to the socio-political context, there must be a thorough leadership problem, so that it is clear that leadership is an essential thing which is actually studied in various scientific disciplines [8].

Basically, leadership and governance are two different theoretical concepts. Leadership is often defined as the techniques, methods, styles and strategies of a leader in influencing others in the process of achieving goals. Government is a container or institution where the ruler (government) and the people (who are governed) interact. Government leadership is the ability or skill of a leader to influence others in achieving government goals in [9].

A leader can do various ways in influencing other people or subordinates to want to do what he orders. This is important because after all a leader has a role as a figure who can be used as an example by his subordinates. In addition, leaders are also touted as leaders who function to make interpersonal relationships with their subordinates by leading, motivating, developing, and controlling their subordinates so that they work in accordance with their respective authority and responsibilities. [10] says that being a participatory leader means involving team members in decision making. This is especially important when creative thinking is required to solve complex problems or make decisions that will impact the inner team [11].

According to [12], leadership is defined as an activity to influence people to achieve organizational goals. Meanwhile, leadership according to [13] is a way for a leader to influence the behavior of subordinates so that 
they are willing to work together and work productively to achieve organizational goals. Leadership is a process of appreciating other people to understand and agree on what needs to be done and how it can be carried out effectively, and the process of facilitating individual or group (collective) efforts to fulfill main goals in [14].

Leader and leadership, where both have different meanings as well as government and government. According to [15], the concept of leadership basically comes from the word "pimpin" which means guide or guide. From the word "pimpin" gives birth to the verb "to lead" which means to guide or guide and the noun "leader" is a person who functions to lead, or a person who guides or guides. Meanwhile, leadership is a person's ability to influence others in achieving goals in [16].

[17] definition of leadership varies as much as people who try to define the concept of leadership. The definition of leadership broadly includes the influence process in determining organizational goals, motivating follower behavior to achieve goals, influencing to improve the group and its culture. Three important implications are contained in this, namely: 1) Leadership involves other people, both subordinates and followers 2) Leadership involves distributing power between the leader and group members equally, because group members are not helpless 3) The ability to use forms of power different ways to influence the behavior of his followers in various ways. Leadership is a management function to influence, direct, motivate and supervise others in order to carry out planned tasks so as to achieve organizational goals and objectives. The leadership ability or leadership of a manager will greatly affect organizational performance, especially in terms of achieving organizational goals. There are many management experts who formulate these definitions of leadership or leadership. One of them is the definition of leadership according to Gareth Jones and Jennifer George (2010: 440). According to him, leadership is a process where an individual has an influence on others and inspires, encourages, motivates and directs their activities in order to help achieve group or organizational goals in [18].

According to [19] that a leader has intelligence, is accountable, healthy and has traits such as adult, freedom of social relations, self-motivation and encouragement of achievement and an attitude of human working relations. On the other hand, in modern social reality, charismatic leaders are also known, especially in the social and political environment. Then according to [20] that charismatic leaders have loyalty and responsibility and support from their followers. The function of the leader is more to provide consultation, guidance, motivation and provide advice in order to achieve goals in [21].

[22] defines leadership as the process of inspiring all employees to work their best in order to achieve the expected results. Leadership is also a major dimension that determines organizational performance. Where the main essence of leadership is an effort to influence people to be more effective, because the leadership can be different depending on the character, characteristics of the task and who they lead [23].

\section{METHODOLOGY}

The research method used in this research is to use qualitative methods. According to [24] qualitative research means the process of exploring and understanding the meaning of individual and group behavior, describing social problems or humanitarian problems. The research process includes making research questions and procedures that are still provisional, collecting data on participant settings, inductive data analysis, building partial data into themes, and then providing interpretations of the meaning of data.

To measure the characteristics of the study are:

1. Performed under natural conditions (as opposed to experimental), the researcher goes directly to the data source and the researcher is a small instrument. Natural conditions are conditions as they are, the researcher does not perform treatments that can affect the scientific object under study.

2. Qualitative research is more descriptive. The data collected is in the form of words or image sources, so it does not emphasize numbers. The data collected after being analyzed is then described so that it is easily understood by others.

In this study, the informants who are competent and have relevance to this research are the sources of information. The informants in this study are actors who really know and master the problems of this research.

To obtain accurate information, the research used the following data collection techniques: Technique of interview (interview) One of the main tools used in gathering information, interviewing involves asking a question of a person or group and recording the answers. If the information meets the research objectives, the questioning will be ended. Interviews conducted in the process of this research used a structured interview technique which was conducted with prepared interview guidelines. Observation Technique, That is, the researcher makes direct observations in the field of the object of research to see social facts and facts so that they can be matched between the results of interviews or information from informants with facts in the field. Documentation Techniques, Researchers collect data with data collection techniques that are not directly addressed to the research subject but study documents related to this research such as books, journals, and so on. This technique can make it easier for the writer to prove that the writer has done research directly into the field.

\section{RESULTS AND DISCUSSION}

Protection comes from the word protection which means, to protect, prevent, defend, and fortify while protection means conservation, maintenance, guarding. Protecting means giving a sense of security, a place of refuge both physically and mentally from any party, whether in the form of a living being or against a person. Objects that are protected by their existence, and this has become the responsibility of all Kuantan Singingi people, especially 
the Tourism and Culture Office. In the operational work concept of the Tourism and Culture Office there is no including protection of cultural heritage, there are only a few operational work concepts, namely:

1. Human resource development in the tourism sector.

2. Development of the traditional cultural values of Kuantan Singingi.

3. Fostering and developing regional arts.

4. Tourism Development in Kuantan Singingi Regency.

5. Promotion and documentation.

6. Formulation of regional law products regarding tourism taxes and levies.

From several operational work concepts the Tourism and Culture Office does not include the protection of cultural heritage, the Tourism and Culture Office should be able to protect these cultural heritage through the concept of operational work.

From the responses of the community respondents, they already know that they can participate in protecting cultural heritage, based on the sub-district arts council, they disagree because of the 26 respondents there are 16 people or $61.5 \%$ who respond less agree.

Interview with the Head of the Tourism and Culture Office who received information that the Department of Tourism and Culture has conducted seminars and outreach to the community, especially the sub-district branch of the arts council about the importance of the community taking part in protecting cultural heritage, but some people who know that they are not really involved in protecting it, because of its obstacles the community does not know that it is a protected cultural heritage and does not know the history of the cultural heritage.

From the information obtained by researchers, it shows that the development of tourism in Kuantan Singingi Regency is indeed the leader who becomes the sole actor because the function of a leader is to organize and organize properly so that tourism can develop into good tourism and provide input to income for the local government of Kuantan Singingi Regency.

The Department of Tourism and Culture as an agency of part of the state's duties certainly has an important role in providing satisfaction to the community, but in its implementation there are often obstacles both from the government and from the community itself such as the lack of seriousness of the government in carrying out its duties and lack of public awareness in terms of matters get in touch with the government.

\section{CONCLUSION}

The conclusion of this study shows that the leadership of the Tourism and Culture Office of Kuantan Singingi Regency has not been maximal in carrying out its duties in accordance with the roles and functions of the Government. So that there will be good cooperation between the Government and the community in developing Cultural Heritage in the area of Kuantan Singingi Regency to result in the preservation of tourism sources, especially the Cultural Heritage which will certainly have a positive impact on the government and society, both economic and other impacts.

\section{ACKNOWLEDGMENTS}

This study is Research Grants by The Ministry of Research and Technology / the National Agency for Research and Innovation of the Republic of Indonesia year 2020.

\section{REFERENCES}

[1] J. Fawcett, "Editorial: But is It Nursing Research?," West J Nurs Res, vol. 22, no. 5, pp. 524-525, 2000, doi: 10.1177/01939450022044575.

[2] M. Thoha, Perilaku Organisasi. 2009.

[3] F. Ali, Teori dan Konsep Administrasi. .

[4] P. S. Siagian, Manajemen Sumber Daya Manusia, 2nd ed. Bumi Aksara, 2001.

[5] S. P. Atmosudirjo, Dasar-dasar administrasi niaga (business asministration). 1982.

[6] S. W. Atmosudarmo, Administrasi negara: sebuah pedoman kerdja. Jakarta: Lembaga Administrasi Negara, 1961.

[7] S. Sagala, "Pengembangan dan Implementasi Kurikulum Penting untuk Meningkatkan Kualitas Pembelajaran," 2000, [Online]. Available: https://123dok.com/document/q05g8r9ypengembangan-implementasi-kurikulum-pentinguntuk-meningkatkan-kualitas-pembelajaran.html.

[8] R. Adiwilaga, Kepemimpinan Pemerintahan Indonesia (Teori dan Prakteknya). Yogyakarta: Budi Utama, 2018.

[9] J. Nas, "Diskursus Kepemimpinan Pemerintahan Kontemporer," Government: Jurnal Ilmu Pemerintahan, vol. 8, no. 1, pp. 1-8, 2015.

[10] D. Gary, "Manajemen Sumber Daya Manusia," 2002, Accessed: Jan. 04, 2021. [Online]. Available:

http://repository.usu.ac.id/bitstream/handle/123456 789/26314/Reference.pdf;jsessionid=E262FCF93B 308F676698FE28AB3581B4? sequence=2.

[11] D. Ahmad Mustanir, Madaling, Andi Uceng, M.Nurzin R. Kasau, Barisan and Andriani, "Karakteristik Kepemimpinan Lurah Terhadap Partisipasi Masyarakat Dalam Musyawarah Perencanaan Pembangunan di Kelurahan Duampanua Kecamatan Baranti Kabupaten Sidenreng Rappang," Jurnal Ilmiah Clean Government, vol. 2, no. 2, pp. 145-172, 2019.

[12] E. Mulyasa, Kurikulum Berbasis Kompetensi; Konsep Karakteristik, dan Implementasi. Bandung: Rodya Karya, 2004.

[13] Hasibuan, Manajemen Sumber Daya Manusia. Hasibuan: Bumi Aksara, 2010.

[14] N. P. D. Y. Peramesti and D. Kusmana, "Kepemimpinan Ideal Pada Era Generasi Milenial," TRANSFORMASI: Jurnal Manajemen Pemerintahan, pp. 73-84, 2018, doi: 10.33701/jt.v10i1.413. 
[15] P. Harbani, Kepemimpinan Birokrasi. Bandung: CV. Alfabeta, 2008.

[16] L. C. S. Paembonan, "Pemerintahan Dan Partisipasi Masyarakat," Socine Polites, pp. 237254, 2011.

[17] V. Rivai and D. Mulyadi, Kepemimpinan dan Perilaku Organisasi, 4th ed. 2008.

[18] D. Betao, K. Pitu, R. Kabupaten, and S. Rappang, "Herman D. 1, Ratna 2 Fakultas Ilmu Sosial dan Ilmu Politik, Universitas Muhammadiyah Rappang,” vol. 8, no. 1, pp. 112-131, 2020.

[19] Wahjosumidjo, Kepemimpinan Kepala Sekolah. Jakarta: Raja Grafindo Persada, 1999.

[20] B. F. Edwin, Manajemen Personalia. Jakarta: Erlangga, 2000.
[21] M. Marpaung, "Pengaruh Kepemimpinan Dan Team Work Terhadap Kinerja Karyawan Di Koperasi Sekjen Kemdikbud Senayan Jakarta," jurnal ilmiah WIDYA, vol. 2, no. 1, pp. 33-40, 2014.

[22] P. Anoraga, Psikologi Kepemimpinan. Jakarta: Rineka Cipta, 2003.

[23] A. Latif, A. Mustanir, and I. Irwan, "Pengaruh Kepemimpinan Terhadap Partisipasi Masyarakat Pada Perencanaan Pembangunan," JAKPP (Jurnal Analisis Kebijakan dan Pelayanan Publik), vol. 5, no. 2, pp. 144-164, 2019.

[24] J. W. Creswell, Research Design (Pendekatan Kualitatif, Kuantitatif, dan Mixed). Yogyakarta: Pustaka Pelajar, 2009. 